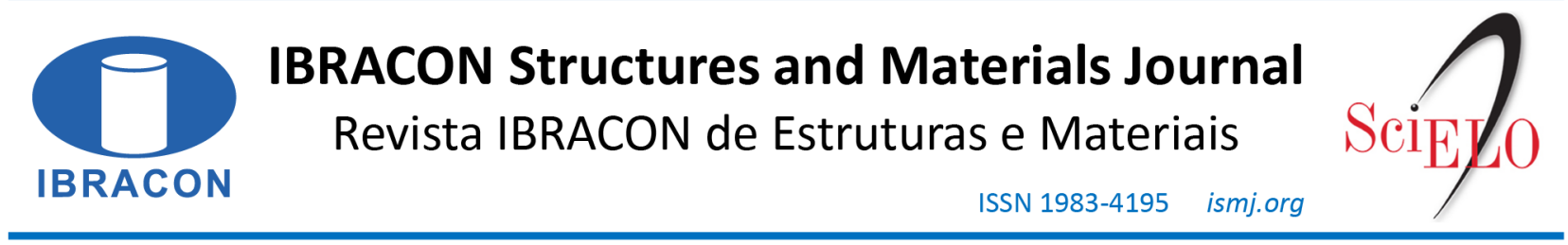

ORIGINAL ARTICLE

\title{
Influence of cement type, air-entrained admixture and hydration stabilizing admixture on mortars' setting time
}

\section{Influência do tipo de cimento e dos aditivos incorporador de ar e estabilizador de hidratação no tempo de pega de argamassas}

\author{
Juliana Pippi Antoniazzi ${ }^{\mathrm{a}}$ (C) \\ Gihad Mohamad ${ }^{\mathrm{b}}$ (D) \\ Juliana Machado Casalic (D)
}

\begin{abstract}
${ }^{a}$ Universidade Federal de Santa Maria - UFSM, Departamento de Expressão Gráfica, Santa Maria, RS, Brasil

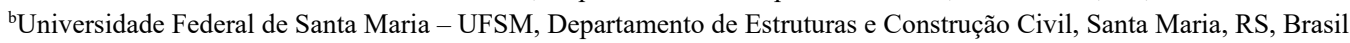

'Instituto Federal de Santa Catarina - IFSC, Departamento Acadêmico de Construção Civil, Florianópolis, SC, Brasil
\end{abstract}

Received 09 September 2019 Accepted 12 June 2020

\begin{abstract}
Ready mix mortar is a ready to use mixture that uses hydration stabilizing (HSA) and air-entrained (AEA) admixtures in its composition, which modify its properties, especially the setting times. HSA extends the setting time of mortars for a long period, while AEA promotes a greater workability to the mixture. The study determined the temperature of the mortars with the evaluation of the setting times obtained by a semiadiabatic calorimeter. Two types of cement (CPII-F-40 e CPII-Z-32) and varied contents of HSA $(0.0 \%, 0.6 \%$ e $0.9 \%)$ and AEA $(0.0 \%, 0.2 \%$ e $0.4 \%)$ were used. The results showed that the use of HSA decreased the amplitude of the temperature peaks and increased the setting times with cement CPII-Z-32 in relation to cement CPII-F-40. The setting time of the mortars was influenced by the type of cement used and by the contents of the admixtures.
\end{abstract}

Keywords: air-entrained admixture, hydration stabilizing admixture, ready mix mortar, setting time.

\begin{abstract}
Resumo: A argamassa estabilizada é uma mistura pronta que faz uso dos aditivos estabilizador de hidratação $(\mathrm{AEH})$ e incorporador de ar (AIA) em sua composição, os quais modificam suas propriedades, principalmente, os tempos de pega. O AEH prorroga o tempo de pega das argamassas por um longo período, enquanto o AIA promove maior trabalhabilidade à mistura. $\mathrm{O}$ estudo determinou a temperatura de argamassas com a avaliação dos tempos de pega obtidos em calorímetro semi-adiabático. Foram utilizados dois tipos de cimento (CPII-F40 e CPII-Z-32) e variados os teores de AEH $(0.0 \%, 0.6 \%$ e $0.9 \%)$ e AIA $(0.0 \%, 0.2 \%$ e $0.4 \%)$. Os resultados mostraram que o uso de AEH diminuiu a amplitude dos picos de temperatura e aumentou os tempos de pega das argamassas com o cimento CPII-Z-32 em relação ao cimento CPII-F-40. O tempo de pega das argamassas foi influenciado pelo tipo do cimento utilizado e pelos teores de aditivos.
\end{abstract}

Palavras-chave: aditivo incorporador de ar, aditivo estabilizador de hidratação, argamassa estabilizada, tempo de pega.

How to cite: J. P. Antoniazzi, G. Mohamad, and J. M. Casali, "Influence of cement type, air-entrained admixture and hydration stabilizing admixture on mortars' setting time," Rev. IBRACON Estrut. Mater., vol. 14, no. 1, e14114, 2021, https://doi.org/10.1590/S198341952021000100014

\section{INTRODUCTION}

The use of ready mix mortar as a coating has been increasing in construction sites of big cities. These mortars arrive ready at the site for its use, and remain workable for up to 72 hours. These characteristics are due to the use of admixtures in the composition of the mixtures; the most common ones being hydration stabilizing admixture (HSA) and airentrained admixture (AEA). 
Air-entrained admixtures (AEA) are organic materials that belong to the class of the surfactants, usually of a cationanion characteristic, being constituted with an (apolar) hydrophobic extremity and another(polar) hydrophilic one [1]. These admixtures decrease the superficial tension and modify the rheology of the mortars through the insertion of small air bubbles, offering a better plasticity [2]. The improvement in the workability of the mixtures is the main effect of the air-entrained admixture when used in mortars [2], [3], but it can also contribute to the delay of the reactions, since its molecules join the cement particles through its polar part (attraction through opposing charges), with the apolar tail focused towards the water [3]. This way, a layer of surfactants is formed around the cement particles which repels the water and may retard the reactions of hydration, depending on the quantity of admixture employed [4]. The permeability of the mortars may also increase with great quantities of entrained air, provided by the excess of AEA [3], and a decrease of the compressive strength may occur [4].

Hydration stabilizing admixtures (HSA) are substances composed by an aqueous salt solution, hydrocarboxylated acids and carbohydrates, that form long-lasting hydration delaying admixtures [5], which promote an increase of the plasticity of the mortar for a greater period of time [6], [7]. When added to mortars they act over all of the minerals of the clinker, reducing the concentration of calcium sulphate in the solution and forming a semipermeable layer around the cement particles, which extends the time of its reactions and of the setting time [7]-[9]. In ready mix mortars they are added together with kneading water, inhibiting the nucleation and formation of hydrated calcium silicates [8], [10], the main responsible for the compressive strength in hardened mortars. This way, HSA increases the period of induction and alters the rate of hydration of the compounds [11], [12]. However, the effects of the admixture on the process of Portland cement may vary according to its chemical basis, occurring in an isolated or simultaneous way [13]. This way, the formation of the hydrates may suffer delay, due to the adsorption of the molecules of the admixture through the surface of the cement particles [11]. Besides this, the chelating property of the molecules of the admixture may also hinder the precipitation and stabilize the dissolved calcium ions [14].

When the effect of the admixture disappears and the barrier formed is dissolved, the cement starts spontaneously to hydrate, and the mortar tends to start its setting process [4], [10].

The rate of HSA employed interferes directly in the time of the blocking of the reactions [15], being even able to act in such a way that the setting process does not occur or that an unwanted setting process ends up occurring. Besides this, when used in excessive quantities, the stabilizing admixture reduces expressively the compressive strength of the mortar [15]-[17].

This way, the employment and the dosage of the admixture in stabilized mortars requires specific studies and domain of the variables involved in the process. Many factors may affect the performance of these mortars, with the possibility of compromising its properties in the fresh and hardened states. The period of time and the procedure of the mixture, the type and the rate of the admixtures used, the compatibility of the admixtures with the cement employed, the consumption of the cement, the temperature and humidity, the type and granulometry of the aggregates, the quality of the water and the form of storage of the ready mix mortar are some of these factors [3], [18]-[20].

The setting times of the ready mix mortars are important factors during its dosage, once it is these mortars that are precisely commercialized with the objective of increasing the time of workability, therefore being necessary to increase the initial time of the reactions. These times depend, among other factors, on the quantity of admixtures employed. Campos [21] determined the setting time of the mortars with HSA, verifying a direct relationship with the admixture content, as well Ruppenthal and Pelisser [22], Pivetta et al. [23]. Calçada et al. [19] also found this relationship, whereas Guindani [13] verified one for stabilized pastes.

The initial setting times obtained by Campos [21] by the method of strength to penetration, according to NBR NM 9 [24], were superior to the ones obtained by a semi-adiabatic calorimeter and by ultrasound, which were also found by Macioski [20] in their analysis with batches of ready-mix mortars. Barbosa et al. [25] evaluated admixtures pastes and mortars with only one rate of HSA by verifying the direct influence of the water over the setting time of the pastes, while the presence of HSA increased the setting time of both. The setting time of the mortars with a HSA were inferior to the pastes with HSA, for the same relations of water/cement, demonstrating the quantity of water available in the system. According to Viecili et al. [26], the method of semi-adiabatic calorimetry proved to be adequate for the determination of the setting times of the pastes made with different types of cement, when comparing them with the results of the method of Vicat. The authors obtained the most coherent results for the setting times by the analysis of the derivatives method.

Other factors that may affect the speed and the quantity of heat liberated in the reactions of hydration are the type and the fineness of the cement. The finer the cement, the faster it will tend to react, once the hydration occurs from the surface to the interior of the grain [27]. With a greater quantity of particles per unit of mass, and, therefore, a greater area of surface in contact with the water, the rate of reactivity tends to be greater [28], [29]. However, none of the 
studies mentioned evaluated the influence of HSA and AEA in different dosages and combinations over the setting times of the mortars. The effect of these admixtures over different types of cement was also not evaluated.

In view of the still existent gaps and the absence of specific norms for the employment of admixtures in ready-mix mortars, this study monitored the temperature of the mortars during the process of hydration, using two distinct types of cement (CPII-F-40 e CPII-Z-32) and different rates of air entrained (AEA) and hydration stabilizing admixtures (HSA). Therefore, the objective was to establish comparatives related to the setting times of the mortars for each type of cement, estimated by different methods of calculus (tangent, direct fraction and derivatives method), evaluating the conjunct and isolated action of each admixture.

\section{MATERIALS AND EXPERIMENTAL PROGRAM}

\subsection{Materials}

The study evaluated the temperature in the initial ages of the mortars using two types of Portland cement, varying the dosages of hydration stabilizing (HAS) and air entrained admixtures (AEA), in order to obtain the initial and final setting times of these. The mortars were made in laboratory, with the materials employed supplied and chosen due to their use by manufacturers of ready-mix mortar of the south region of the country.

The cements used in this research were a Portland cement composed with carbonate material (CPII-F-40) and a Portland cement composed with pozzolanic material (CPII-Z-32), both from the same manufacturer, denominated in this research as cement $F$ and cement $Z$, respectively. The tests of characterization of Portland cement are found in Table 1 and Table 2.

Table 1. Physical characteristics of cements CPII F-40 and CP II Z-32.

\begin{tabular}{cccc}
\hline Property & Cement F & Cement Z & Method \\
\hline Specific mass $\left(\mathrm{g} / \mathrm{cm}^{3}\right)$ & 3.10 & 3.06 & ABNT NBR 16605 [30] \\
\hline Fineness index $(\# 0.075 \mathrm{~mm})(\%)$ & 0.12 & 0.51 & ABNT NBR 11579 [31] \\
\hline Percentage of water for normal consistency $(\%)$ & 29.00 & 28.71 & ABNT NBR 16606 [32] \\
\hline Initial setting $(\mathrm{h}: \mathrm{min})$ & $4: 00$ & $4: 10$ & ABNT NBR 16607 [33] \\
\hline Final setting $(\mathrm{h}: \mathrm{min})$ & $5: 20$ & $5: 44$ & ABNT NBR 16607 [33] \\
\hline Surface area $\left(\mathrm{m}^{2} / \mathrm{g}\right)$ & 1.2592 & 1.2844 & BET \\
\hline Pore volume $\left(\mathrm{cm}^{3} / \mathrm{g}\right)$ & 0.004791 & 0.004190 & BET \\
\hline Pore dimension $(\mathrm{nm})$ & 20.0047 & 17.7925 & BJH/BET \\
\hline
\end{tabular}

Table 2. Chemical, physical, and mechanical characteristics of cements CPII F-40 and CP II Z-32.

\begin{tabular}{|c|c|c|c|c|c|}
\hline \multicolumn{6}{|c|}{ Chemical Tests } \\
\hline & & Cement F & Cement Z & Code Limit & Normative \\
\hline \multicolumn{2}{|c|}{ Ignition loss $(\%)$} & 4.86 & 5.26 & $\leq 6.5$ & ABNT NBR NM 18 [34] \\
\hline \multicolumn{2}{|c|}{ Magnesium oxide (\%) } & 5.90 & 5.52 & $\leq 6.5$ & ABNT NBR NM 14 [35] \\
\hline \multicolumn{2}{|c|}{ Sulfur trioxide (\%) } & 3.56 & 2.83 & $\leq 4.0$ & ABNT NBR NM 16 [36] \\
\hline \multicolumn{2}{|c|}{ Insoluble residue $(\%)$} & 0.82 & 13.17 & $\leq 2.5 / \leq 16$ & ABNT NBR NM 22 [37] \\
\hline \multicolumn{6}{|c|}{ Physical and Mechanical Tests } \\
\hline \multicolumn{2}{|c|}{ Blaine $\left(\mathrm{cm}^{2} / \mathrm{g}\right)$} & 4521.50 & 3657.50 & $\geq 2800 / \geq 2600$ & ABNT NBR 16372 [38] \\
\hline \multicolumn{2}{|c|}{ Hot expansibility (mm) } & 0.38 & 0.55 & $\leq 5.0$ & ABNT NBR 11582 [39] \\
\hline \multirow{4}{*}{$\begin{array}{l}\text { Compression } \\
\text { strength }\end{array}$} & 1 day & 23.73 & 12.51 & N/A & \multirow{4}{*}{ ABNT NBR 7215 [40] } \\
\hline & 3 days & 34.47 & 22.89 & $\geq 15.0 / \geq 10.0$ & \\
\hline & 7 days & 40.25 & 28.17 & $\geq 25.0 / \geq 20.0$ & \\
\hline & 28 days & 47.68 & 37.13 & $\geq 40.0 / \geq 32.0 ; \leq 49.0$ & \\
\hline
\end{tabular}

Source: Portland Cement Manufacturer

The fine aggregate employed (sand) is natural, from the river of the city of Santa Maria/RS, with its characteristics specified on Table 3. The choice of this aggregate was due to the study conducted by Antoniazzi [45]. In this study 
statistically significant differences were not found related to the entrainment of air for mortars made with different granulometries. Therefore, the material with greater viability and easiness of access was chosen.

Table 3. Properties of the small aggregate.

\begin{tabular}{ccc}
\hline Propriety & Sand & Method \\
\hline Maximum characteristic dimension $(\mathrm{mm})$ & 1.20 & ABNT NBR NM 248 [41] \\
\hline Fineness module & 1.73 & ABNT NBR NM 248 [41] \\
\hline Specific mass $\left(\mathrm{g} / \mathrm{cm}^{3}\right)$ & 2.64 & ABNT NBR NM 52 [42] \\
\hline Unit mass $\left(\mathrm{g} / \mathrm{cm}^{3}\right)$ & 1.63 & ABNT NBR NM 45 [43] \\
\hline Content of pulverulent $\mathrm{meterial}^{2}(\%)$ & 4.94 & ABNT NBR NM 46 [44] \\
\hline Surface area $\left(\mathrm{m}^{2} / \mathrm{g}\right)$ & 0.5424 & BET \\
\hline Pore volume $\left(\mathrm{cm}^{3} / \mathrm{g}\right)$ & 0.001156 & BET \\
\hline Pore dimension $(\mathrm{nm})$ & 8.4833 & BJH/BET \\
\hline
\end{tabular}

Source: Author.

The granulometry of the aggregate was conducted according to NBR NM 248 [41] and may be verified in Figure 1. Before the preparation of the mortars, the aggregates were dried in an oven during 24 hours.

\begin{tabular}{ccc}
\hline & \multicolumn{2}{c}{ Sand } \\
\cline { 2 - 3 } $\begin{array}{c}\text { Meshes } \\
\text { opening } \\
\text { (mm) }\end{array}$ & \% Retained & $\begin{array}{c}\text { Cumulative } \\
\text { Retained } \\
\text { Percentage }\end{array}$ \\
\hline 9.50 & $0.00 \%$ & $0.00 \%$ \\
4.80 & $0.08 \%$ & $0.08 \%$ \\
2.40 & $0.40 \%$ & $0.47 \%$ \\
1.20 & $1.78 \%$ & $2.25 \%$ \\
0.60 & $15.19 \%$ & $17.45 \%$ \\
0.30 & $51.31 \%$ & $68.76 \%$ \\
0.15 & $15.33 \%$ & $84.08 \%$ \\
Bottom & $15.92 \%$ & $100.00 \%$ \\
\hline
\end{tabular}

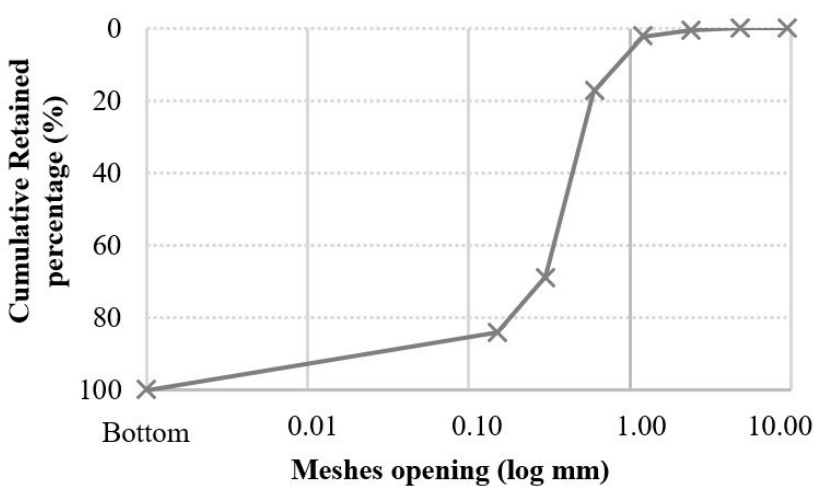

Figure 1. Particle size of Sand.

The mortars were prepared using two types of admixtures, an air entrained admixture (AEA) and a hydrating stabilizing (HAS). The technical data, supplied by the manufacturer, is found on Table 4.

Table 4. Technical data of the air-entrained admixture (AEA) and hydration stabilizing admixture (HSA).

\begin{tabular}{ccc}
\hline Characteristics & AEA & HSA \\
\hline Chemical base & Sulfated ethoxylated fatty alcohol salt & Liquid \\
\hline Aspect & Liquid & Brown \\
\hline Color & Yellow & 1.17 \\
\hline Density $\left(\mathrm{g} / \mathrm{cm}^{3}\right)$ & 1.00 & 45 \\
\hline Solids content $(\%)$ & 3 & 6 \\
\hline $\mathrm{pH}$ & 9 & Soluble in water \\
\hline Solubility & Soluble in water $\left(20^{\circ} \mathrm{C}\right)$ & $0.2-1.5$ \\
\hline
\end{tabular}

Source: Admixtures manufacturer. 


\subsection{Experimental Program}

All of the tests were conducted in the Civil Engineering and Material Laboratory - CEML - and in the Environmental Processes Laboratory - EPL - both of Federal University of Santa Maria (UFSM).

Eighteen mortars were prepared with the same proportion in mass of 1:6.5, relation of water/cement of 1.0 and fine aggregate. The dosages of the admixtures used were varied, with the rates of $0.0 \%, 0.6 \%$ e $0.9 \%$ of HAS and of $0.0 \%$, $0.2 \%$ e $0.4 \%$ of AEA being employed, related to the cement mass. Of the eighteen mortars prepared, nine used Cement $\mathrm{F}$ and nine used Cement $\mathrm{Z}$ Table 5 presents the mortars studied in this research with its respective denominations.

Table 5. Mortar mixtures with cements $\mathrm{F}$ and $\mathrm{Z}$.

\begin{tabular}{|c|c|c|c|c|}
\hline Mortar & HSA (\%) & AEA (\%) & Type of cement & Nomenclature \\
\hline \multirow{2}{*}{$\mathrm{A} 1(0.0 / 0.0)$} & \multirow{2}{*}{0.0} & \multirow{2}{*}{0.0} & Cement $\mathrm{F}$ & $\mathrm{A} 1 \mathrm{~F}(0.0 / 0.0)$ \\
\hline & & & Cement Z & $\mathrm{A} 1 \mathrm{Z}(0.0 / 0.0)$ \\
\hline \multirow{2}{*}{$\mathrm{A} 2(0.6 / 0.0)$} & \multirow{2}{*}{0.6} & \multirow{2}{*}{0.0} & Cement $\mathrm{F}$ & A2F $(0.6 / 0.0)$ \\
\hline & & & Cement Z & A2Z(0.6/0.0) \\
\hline \multirow{2}{*}{$\mathrm{A} 3(0.9 / 0.0)$} & \multirow{2}{*}{0.9} & \multirow{2}{*}{0.0} & Cement $\mathrm{F}$ & A3F(0.9/0.0) \\
\hline & & & Cement Z & A3Z(0.9/0.0) \\
\hline \multirow{2}{*}{$\mathrm{A} 4(0.0 / 0.2)$} & \multirow{2}{*}{0.0} & \multirow{2}{*}{0.2} & Cement $\mathrm{F}$ & $\mathrm{A} 4 \mathrm{~F}(0.0 / 0.2)$ \\
\hline & & & Cement Z & $\mathrm{A} 4 \mathrm{Z}(0.0 / 0.2)$ \\
\hline \multirow{2}{*}{$\mathrm{A} 5(0.0 / 0.4)$} & \multirow{2}{*}{0.0} & \multirow{2}{*}{0.4} & Cement $\mathrm{F}$ & $\mathrm{A} 5 \mathrm{~F}(0.0 / 0.4)$ \\
\hline & & & Cement Z & A5Z(0.0/0.4) \\
\hline \multirow{2}{*}{$\mathrm{A} 6(0.6 / 0.2)$} & \multirow{2}{*}{0.6} & \multirow{2}{*}{0.2} & Cement $\mathrm{F}$ & $\mathrm{A} 6 \mathrm{~F}(0.6 / 0.2)$ \\
\hline & & & Cement Z & $\mathrm{A} 6 \mathrm{Z}(0.6 / 0.2)$ \\
\hline \multirow{2}{*}{$\mathrm{A} 7(0.6 / 0.4)$} & \multirow{2}{*}{0.6} & \multirow{2}{*}{0.4} & Cement $\mathrm{F}$ & A7F(0.6/0.4) \\
\hline & & & Cement Z & A7Z(0.6/0.4) \\
\hline \multirow{2}{*}{$\mathrm{A} 8(0.9 / 0.2)$} & \multirow{2}{*}{0.9} & \multirow{2}{*}{0.2} & Cement $\mathrm{F}$ & $\mathrm{A} 8 \mathrm{~F}(0.9 / 0.2)$ \\
\hline & & & Cement Z & A8Z(0.9/0.2) \\
\hline \multirow{2}{*}{ A9(0.9/0.4) } & \multirow{2}{*}{0.9} & \multirow{2}{*}{0.4} & Cement $\mathrm{F}$ & A9F(0.9/0.4) \\
\hline & & & Cement Z & A9Z(0.9/0.4) \\
\hline
\end{tabular}

The mortars were prepared in a mixer of 5 liters, with planetary movement. The procedure of mixture was performed based on recommendations described in NBR 7215 [40] with adaptations for the use of admixtures and within the time of rest as described below. Initially all of the water was inserted (in the mortars with admixtures, these were added at this moment and mixed in low speed with the water during 20 seconds for homogenization) and, afterwards, all of the Portland cement. With the mixer in low speed, the materials were mixed during 30 seconds. Afterwards, without paralyzing the equipment, the sand was introduced gradually, during a period of 30 seconds. After the sand was inserted, the speed was altered to high and the materials were mixed for another 30 seconds. The mixer was turned off during 15 seconds for the withdrawal of mortar adhered to the walls with the help of a shovel. The mixer was then turned on again in high speed for 180 more seconds, totalizing a full time of 270 seconds, as established by Antoniazzi [45], for a maximum entrainment of air.

For each mixture of mortar three samples were evaluated, which were placed in distinct semi-adiabatic calorimeters. Figure 2 presents a scheme of the system performed, in cut, which consists in an expanded cup of polypropylene (Styrofoam) with a lid, and an internal diameter of $8 \mathrm{~cm}$ and a useful height of $11 \mathrm{~cm}$. This cup was inserted in a box of the same material with a lid, with dimensions of $20 \times 25 \times 28 \mathrm{~cm}$. Both were coated with aluminum paper internally and externally for a better thermal isolation. The cup received the sample of mortar in its interior and had a thermocouple "type t" wire submerged. The space between the two boxes was filled with small spheres of expanded polypropylene (Styrofoam), which were confined by a sheet of expanded polypropylene (Styrofoam) on the superior part. The thermocouple wire was connected to the data collector (Fieldlogger Novus), which was interconnected to a computer with Novus Fieldchart software, for data plotting. This way, each mixture was placed in a calorimeter, where the evolution of the temperature for 336 hours (14 days) was followed up. The collection of the data was programmed to be registered every ten minutes. 


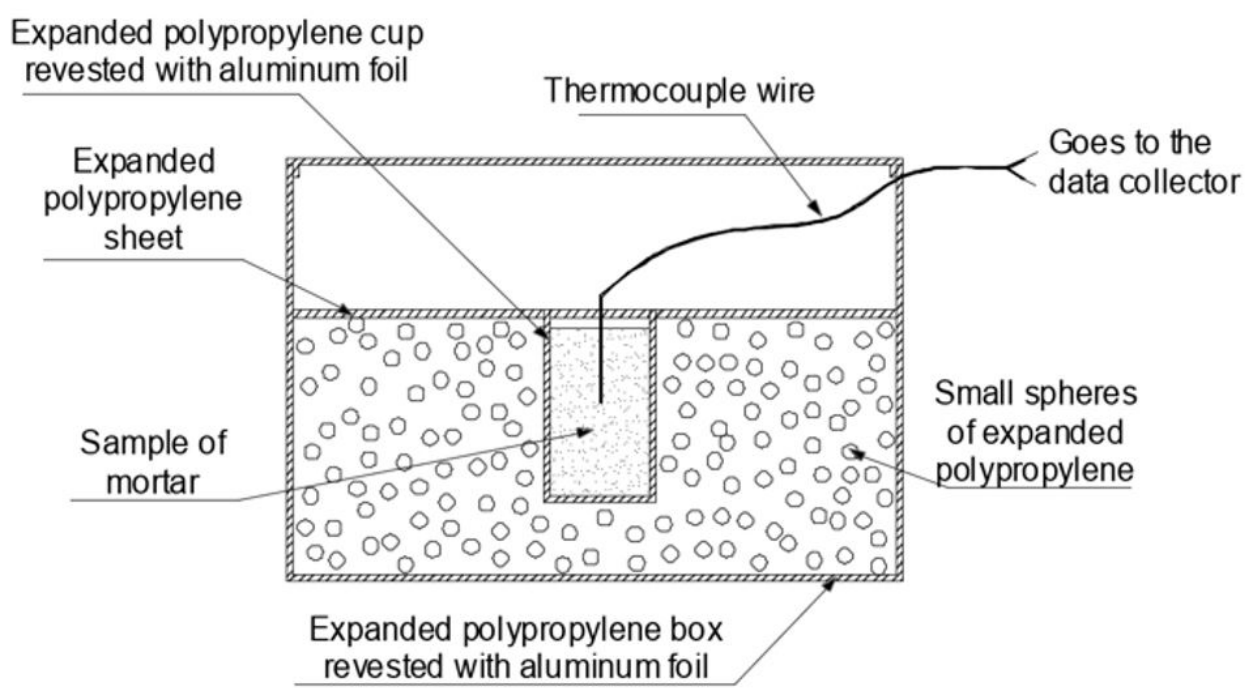

Figure 2. Scheme of the semi-adiabatic calorimeter in section.

The sequence of assembly of the boxes for the rehearsal occurred in the following way: first, a hole was made on the lid of the cup, where the thermocouple wire type $\mathrm{T}$ (Figure 3a) was inserted, with the depth, that should penetrate in the box in order for it to remain always in the same position (half height) inside the samples, being marked. Small spheres of expanded polypropylene were placed (Figure 3b) around the cup containing the sample of mortar in its interior, which was inserted inside a plastic bag to make the reutilization of the cups possible (Figure $3 \mathrm{c}$ ). The filling of the sample was performed in two layers, with 20 blows of metallic socket and 3 falls of approximately $3 \mathrm{~cm}$ in each one, with a volume of mortar of approximately $553 \mathrm{~cm} 3$. The cup with the sample was closed with a lid (Figure 3d), surrounded by spheres of isopropylene and fit into the hole of the plate. The box was also perforated on its side for the passage of the thermocouple wire to the external space (Figure 3e), closing the holes with liquid silicone where the thermocouple wire passed. The thermocouple wire was connected to the data collector (Figure 3f). Based on the data obtained, three distinct methods were used for the analysis and determination of the initial and final setting times: the tangent method [46], direct fraction method [26], [47] and the derivatives method [48]. In each of the methods the times considered for each mixture was the arithmetic mean between the three samples tested.
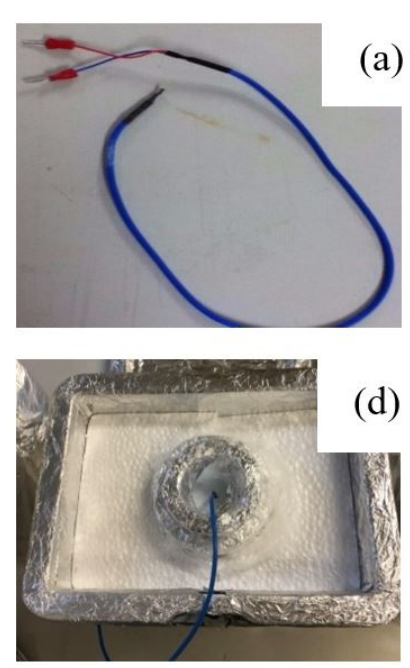
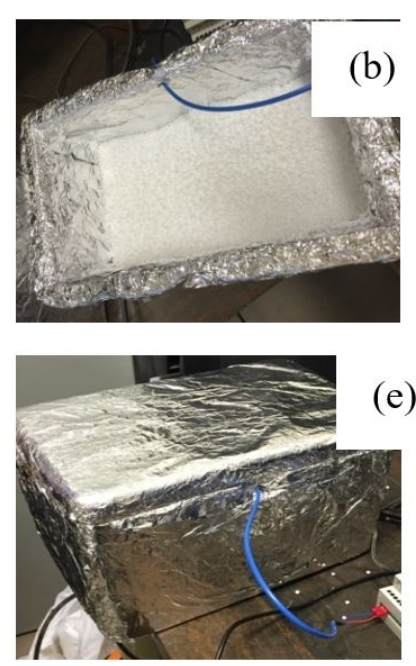

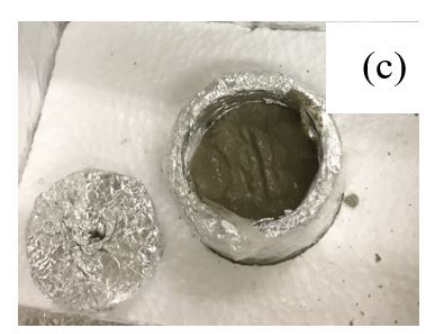

(e)

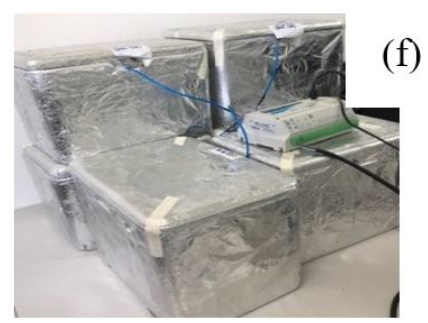

Figure 3. Sequence of the assembly of the boxes for the initial setting time test. (a) thermocouple type T; (b) expanded polypropylene box with cradle for small expanded polypropylene spheres; (c) expanded polypropylene cup positioned inside the box, embedded in expanding polypropylene plate, receiving the mortar sample within; (d) thermocouple positioned within the sample, properly capped and sealed with silicone; (e) closed box with the sample inside and thermocouple exiting the external medium, connecting to the data collector; (f) system ready and connected to the data collector. 
The tangent method, as demonstrated on Figure 4 [46], estimates, based on the values of temperature versus time, the time of the beginning of the setting process through the trace of horizontal lines that tangent the curve in the maximum and minimum temperature points. The tangent lines, by turn, are intercepted by a third line superimposed to the curve in the period of acceleration and reaction to hydration. The points of intersection between the traced lines correspond to the initial and final setting times.

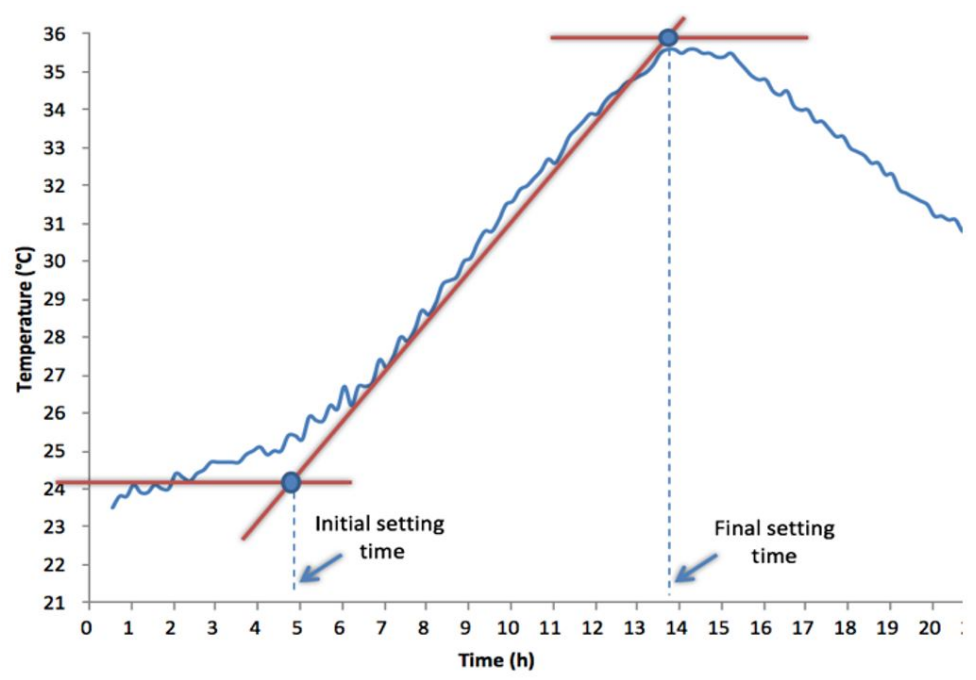

Figure 4. Scheme representing the determination of the initial and final setting times by the tangent method.

Through the direct fraction method [26], [47] the initial and final setting times are determined by percentages of the total increase of the temperature. This way, in controlled environment conditions, the initial setting time is equivalent to $21 \%$ of the difference between the temperature of the beginning of the induction and superior peak of the temperature reached, while the final time is equivalent to $42 \%$, as shown in Figure 5.

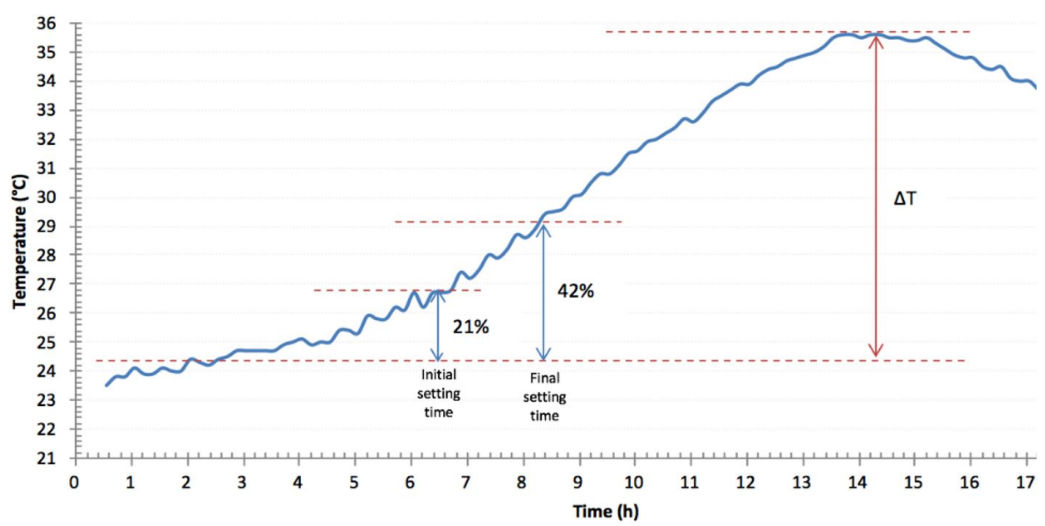

Figure 5. Scheme representing the determination of the initial and final setting times by the direct fraction method.

The derivatives method [48] is based on studies that demonstrated that the initial setting time is equivalent to the maximum peak of temperature of the second derivative of the temperature versus time curve, while the final setting time is obtained through the peak of the first derivative, according to the demonstration on Figure 6.

To allow the analysis of the mortars under the same conditions of molding, testing and temperature $\left(24^{\circ} \mathrm{C}\right)$, the mortars of the same trace and same rate of admixture were simultaneously molded, varying only the type of Portland cement (Cement $\mathrm{F}$ and Cement $\mathrm{Z}$ ). The monitoring of the mortars started $20 \mathrm{~min}$ after the confection of the samples due to the assembly, transportation to the air-conditioned location and connection to the field logger. 


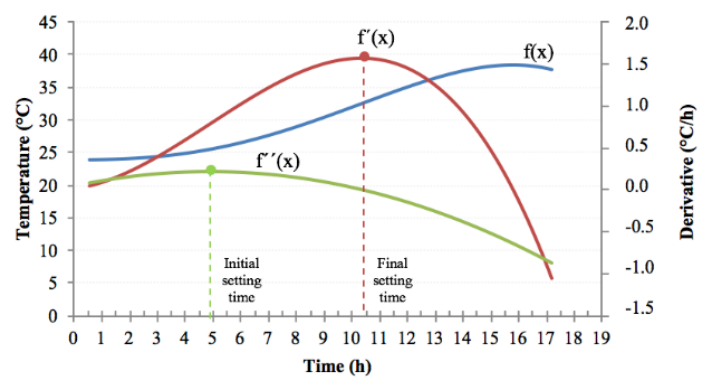

Figure 6. Scheme representing the determination of the initial and final setting times by the derivatives method.

The data of the research was analyzed with the help of the SPSS (Statistical Package for Social Sciences, version 20.0) program, using T Tests and ANOVA with the Tukey Post Hoc Test $(\mathrm{p}<0.05)$ for the comparison of the results between the different mixtures and between mortars with the two types of Portland cement. The determination coefficient $\left(\mathrm{R}^{2}\right)$ was used to classify the adjustment of the data to a regression model, and also Pearson's linear correlation coefficient (r) was calculated, which expresses the intensity and the sense of linear relation existent between the two numeric variables. In data analysis, when $(\mathrm{p}<0.05)$, it is considered that there is a significant statistic difference between the results, otherwise there are no significant differences. When there were differences, the Post Hoc Tukey Test was applied to evaluate which groups are different and which are similar, with superscript letters for identification. When the results receive the same superscript letter this indicates that there are no differences between them, whereas, when the letters are different, they are statistically different.

\section{RESULTS AND DISCUSSIONS}

The curves of the temperature versus time, for each one of the mortars studied are presented in Figure 7, with (a) the mortars prepared with cement $\mathrm{F}$ and (b) the mortars prepared with cement $\mathrm{Z}$ in its composition.
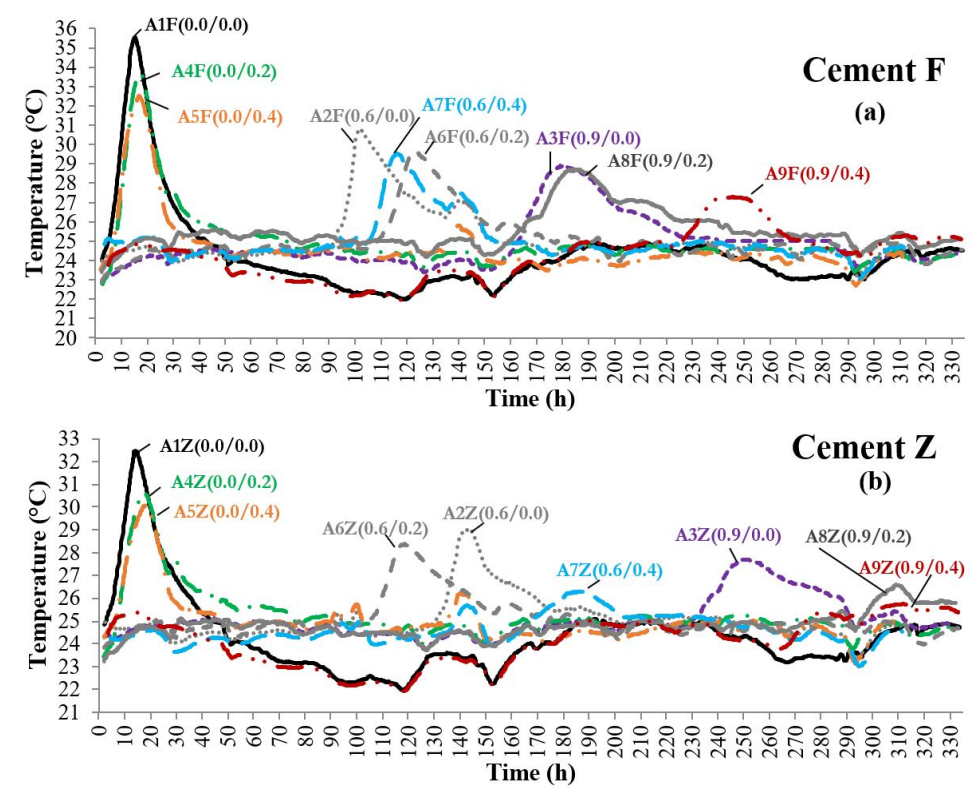

Figure 7. Evolution of the mortar temperatures over time, for cement $F$ (a) and cement $Z$ (b).

It is observed in Figure 7 that the type of Portland cement employed influenced in the process of hydration and in the formation of the hydrated compounds. This behavior was verified because, for a same trace and same rate of admixture, the type of cement used altered almost all of the setting times and peaks of temperature reached. Through the curves of evolution of the temperature with time (Figure 7) it is perceived that the mortars with cement $F$ reached greater temperatures than the ones with cement $Z$, probably due to the greater liberation of heat during its reactions of 
hydration. This may be attributed to the greater fineness of the cement (values of fineness obtained through the method of air entrainment - the Blaine method - Table 2) and also to the fact that cement $Z$ contains a greater quantity of pozzolans (rate of insoluble residues - Table 2), where the quantity of clinker is greater in cement $F$, influencing the rate of hydration of the particles [12]. Like cement $\mathrm{F}$, besides being finer (Table 2), it has a greater rate of anhydrous compounds, such as, for example, tricalcium aluminate $\left(\mathrm{C}_{3} \mathrm{~A}\right)$ and tricalcium silicate $\left(\mathrm{C}_{3} \mathrm{~S}\right)$, increasing the temperature in the first ages due to the liberation of heat through the exothermic reaction of hydration of these components.

A great influence of the HSA admixture in the setting times was observed in the mortars studied. For the two types of cement, the reactions of hydration of Portland cement began during the first hours for mortars $\mathrm{A} 1(0.0 / 0.0), \mathrm{A} 4(0.0 / 0.2) \mathrm{e} \mathrm{A} 5(0.0 / 0.4)$; in other words, for all that did not have HSA in its composition The other mixtures suffered an increase of time during the beginning of the setting process, possibly due to the water repellent layer that HSA forms over the particles of cement [7], [8]. The increase of the initial setting time was influenced directly by the rate of HSA used, through the type of cement and by the combination with AEA. It is also possible to observe that, the greater the quantity of HAS in the composition of the mortar, smaller was the amplitude of the peak of temperature reached, as evidenced in Figure 7 and Figure 8, indicating a greater dissipation of the heat and delay in the rate of hydration of the compounds [13], [15].

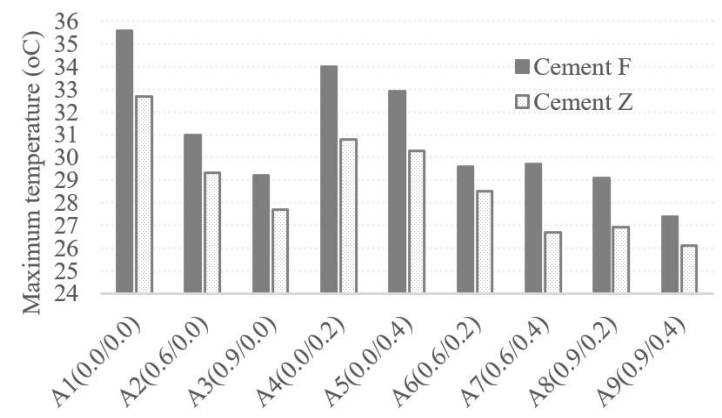

Figure 8. Maximum temperatures reached by mortars with cement $F$ and cement $Z$.

\subsection{Comparison between the methods of determination of the setting times}

Through the data of the temperature due to the time, the initial and final setting times were determined through three methods: of the tangents, direct fractions and of the derivatives. The mean results, followed by the standard deviations, are presented in Tables 6,7 and 8 for the mortars analyzed.

Through the analysis of data of Table 6 , it is observed that there was no statistically different difference between the setting times obtained by the two types of cement, both for mortar A4(0.0/0.2), as well as A5(0.0/0.4). As for mortar A1 $(0.0 / 0.0)$, there were considerable differences $\left(\mathrm{p}^{* *}=0.024\right)$ for the initial setting time; however, the final setting times were similar $\left(\mathrm{p}^{* *}=0.230\right)$.

Table 6. Mortar setting time $(\mathrm{M} \pm \mathrm{SD})$ using cements $\mathrm{F}$ and $\mathrm{Z}$, by the tangent method.

\begin{tabular}{|c|c|c|c|c|c|c|}
\hline \multirow{2}{*}{ Mixture (HSA/AEA) } & \multicolumn{3}{|c|}{ Initial setting time (h) } & \multicolumn{3}{|c|}{ Final setting time (h) } \\
\hline & Cement F & Cement $Z$ & $\mathbf{P} * *$ & Cement F & Cement Z & $\mathbf{P}^{* *}$ \\
\hline A1 $(0.0 / 0.0)$ & $4.17 \pm 0.29^{\mathrm{A}}$ & $3.33 \pm 0.29^{\mathrm{A}}$ & 0.024 & $13.00 \pm 0.29^{\mathrm{A}}$ & $12.83 \pm 0.29^{\mathrm{A}}$ & 0.230 \\
\hline A2 $(0.6 / 0.0)$ & $93.17 \pm 1.26^{\mathrm{B}}$ & $132.00 \pm 1.00^{\mathrm{C}}$ & $<0.001$ & $100.50 \pm 0.50^{\mathrm{B}}$ & $140.17 \pm 0.76^{\mathrm{C}}$ & $<0.001$ \\
\hline A3 $(0.9 / 0.0)$ & $155.50 \pm 1.32^{\mathrm{E}}$ & $227.83 \pm 0.29^{\mathrm{E}}$ & $<0.001$ & $175.50 \pm 0.87^{\mathrm{E}}$ & $246.83 \pm 0.29^{\mathrm{E}}$ & $<0.001$ \\
\hline A4 (0.0/0.2) & $5.33 \pm 0.29^{\mathrm{A}}$ & $4.50 \pm 0.50^{\mathrm{A}}$ & 0.067 & $13.83 \pm 0.29^{\mathrm{A}}$ & $14.00 \pm 0.50^{\mathrm{A}}$ & 0.643 \\
\hline A5 $(0.0 / 0.4)$ & $5.00 \pm 0.50^{\mathrm{A}}$ & $4.50 \pm 0.50^{\mathrm{A}}$ & 0.288 & $14.67 \pm 0.76^{\mathrm{A}}$ & $14.50 \pm 0.50^{\mathrm{A}}$ & 0.768 \\
\hline A6 $(0.6 / 0.2)$ & $110.17 \pm 0.76^{\mathrm{D}}$ & $106.00 \pm 1.73^{\mathrm{B}}$ & 0.019 & $121.67 \pm 0.76^{\mathrm{D}}$ & $117.50 \pm 1.32^{\text {В }}$ & 0.009 \\
\hline A7 $(0.6 / 0.4)$ & $105.00 \pm 0.50^{\mathrm{C}}$ & $153.33 \pm 0.76^{\mathrm{D}}$ & $<0.001$ & $114.17 \pm 0.29^{\mathrm{C}}$ & $182.83 \pm 1.26^{\mathrm{D}}$ & $<0.001$ \\
\hline A8 $(0.9 / 0.2)$ & $154.00 \pm 1.00^{\mathrm{E}}$ & $290.00 \pm 0.50^{\mathrm{G}}$ & $<0.001$ & $183.00 \pm 1.00^{\mathrm{F}}$ & $386.00 \pm 5.67^{\mathrm{G}}$ & $<0.001$ \\
\hline A9 $(0.9 / 0.4)$ & $223.00 \pm 1.00^{\mathrm{F}}$ & $264.33 \pm 0.29^{\mathrm{F}}$ & $<0.001$ & $237.83 \pm 0.76^{\mathrm{G}}$ & $278.17 \pm 2.52^{\mathrm{F}}$ & $<0.001$ \\
\hline $\mathbf{p}^{*}$ & $<0.001$ & $<0.001$ & - & $<0.001$ & $<0.001$ & - \\
\hline
\end{tabular}

p* ANOVA with Tukey com Post Hoc: comparison between the setting times of the nine different mixtures with the same cement; $\mathrm{p}^{* *} \mathrm{~T}$ Test of independent samples: comparison between the setting times obtained by the same mixture with different types of cement. 
Table 7. Mortar setting time $(\mathrm{M} \pm \mathrm{SD})$ using cements $\mathrm{F}$ and $\mathrm{Z}$, by the direct fraction method.

\begin{tabular}{|c|c|c|c|c|c|c|}
\hline \multirow{2}{*}{ Mixture (HSA/AEA) } & \multicolumn{3}{|c|}{ Initial setting time (h) } & \multicolumn{3}{|c|}{ Final setting time (h) } \\
\hline & Cement F & Cement Z & $\mathbf{P} * *$ & Cement F & Cement Z & $\mathbf{P} * *$ \\
\hline A1 $(0.0 / 0.0)$ & $5.76 \pm 0.21^{\mathrm{A}}$ & $5.44 \pm 0.49^{\mathrm{A}}$ & 0.353 & $8.91 \pm 0.17^{\mathrm{A}}$ & $7.45 \pm 0.46^{\mathrm{A}}$ & 0.007 \\
\hline A2 $(0.6 / 0.0)$ & $94.17 \pm 0.65^{\text {В }}$ & $133.36 \pm 0.67^{\mathrm{C}}$ & $<0.001$ & $95.56 \pm 0.94^{\mathrm{B}}$ & $135.30 \pm 0.59^{\mathrm{C}}$ & $<0.001$ \\
\hline A3 $(0.9 / 0.0)$ & $159.54 \pm 1.10^{\mathrm{E}}$ & $231.50 \pm 0.60^{\mathrm{E}}$ & $<0.001$ & $164.09 \pm 0.85^{\mathrm{E}}$ & $236.53 \pm 0.64^{\mathrm{E}}$ & $<0.001$ \\
\hline A4 $(0.0 / 0.2)$ & $7.11 \pm 0.22^{\mathrm{A}}$ & $6.35 \pm 0.40^{\mathrm{A}}$ & 0.053 & $8.90 \pm 0.33^{\mathrm{A}}$ & $8.44 \pm 0.43^{\mathrm{A}}$ & 0.214 \\
\hline A5 $(0.0 / 0.4)$ & $7.16 \pm 0.40^{\mathrm{A}}$ & $6.69 \pm 0.34^{\mathrm{A}}$ & 0.196 & $8.89 \pm 0.40^{\mathrm{A}}$ & $8.28 \pm 0.30^{\mathrm{A}}$ & 0.099 \\
\hline A6 $(0.6 / 0.2)$ & $112.51 \pm 1.02^{\mathrm{D}}$ & $108.43 \pm 1.32^{\mathrm{B}}$ & 0.013 & $114.97 \pm 0.98^{\mathrm{D}}$ & $110.73 \pm 1.28^{\text {B }}$ & 0.010 \\
\hline A7 $(0.6 / 0.4)$ & $106.50 \pm 0.82^{\mathrm{C}}$ & $160.54 \pm 0.98^{\mathrm{D}}$ & $<0.001$ & $108.56 \pm 0.66^{\mathrm{C}}$ & $166.36 \pm 1.04^{\mathrm{C}}$ & $<0.001$ \\
\hline A8 $(0.9 / 0.2)$ & $160.28 \pm 0.72^{\mathrm{E}}$ & $294.55 \pm 0.67^{\mathrm{G}}$ & $<0.001$ & $167.44 \pm 0.58^{\mathrm{F}}$ & $298.16 \pm 1.00^{\mathrm{G}}$ & $<0.001$ \\
\hline A9 $(0.9 / 0.4)$ & $224.65 \pm 0.12^{\mathrm{F}}$ & $266.69 \pm 0.21^{\mathrm{F}}$ & $<0.001$ & $228.34 \pm 0.06^{\mathrm{G}}$ & $270.20 \pm 0.65^{\mathrm{F}}$ & $<0.001$ \\
\hline $\mathrm{p}^{*}$ & $<0.001$ & $<0.001$ & & $<0.001$ & $<0.001$ & \\
\hline
\end{tabular}

p* ANOVA with Tukey com Post Hoc: comparison between the setting times of the nine different mixtures with the same cement; $\mathrm{p}^{* *} \mathrm{~T}$ Test of independent samples: comparison between the setting times obtained by the same mixture with different types of cement.

It is perceived, on Table 7, that the values found also indicate a similarity among the results of the setting time of mortar A4(0.0/0.2) for the two types of cement, also verified for A5(0.0/0.4). In the mixture A1(0.0/0.0), the initial setting times were statistically similar $\left(\mathrm{p}^{* *}=0.353\right)$ and the final setting times divergent $\left(\mathrm{p}^{* *}=0.007\right)$.

Table 8. Mortar setting time $(\mathrm{M} \pm \mathrm{SD})$ using cements $\mathrm{F}$ and $\mathrm{Z}$, by the derivative method.

\begin{tabular}{|c|c|c|c|c|c|c|}
\hline \multirow{2}{*}{ Mixture (HSA/AEA) } & \multicolumn{3}{|c|}{ Initial setting time (h) } & \multicolumn{3}{|c|}{ Final setting time(h) } \\
\hline & Cement F & Cement Z & $\mathbf{P} * *$ & Cement F & Cement Z & $\mathbf{P} * *$ \\
\hline A1 $(0.0 / 0.0)$ & $6.31 \pm 0.27^{\mathrm{A}}$ & $5.67 \pm 0.70^{\mathrm{A}}$ & 0.216 & $8.36 \pm 0.18^{\mathrm{A}}$ & $8.26 \pm 0.25^{\mathrm{A}}$ & 0.774 \\
\hline A2 $(0.6 / 0.0)$ & $94.26 \pm 0.70^{\mathrm{B}}$ & $132.56 \pm 0.80^{\mathrm{C}}$ & $<0.001$ & $98.45 \pm 0.76^{\mathrm{C}}$ & $134.30 \pm 1.22^{\mathrm{D}}$ & $<0.001$ \\
\hline A3 $(0.9 / 0.0)$ & $166.31 \pm 0.85^{\mathrm{F}}$ & $229.74 \pm 0.70^{\mathrm{E}}$ & $<0.001$ & $179.80 \pm 0.86^{\mathrm{G}}$ & $239.77 \pm 0.50^{\mathrm{F}}$ & $<0.001$ \\
\hline A4 $(0.0 / 0.2)$ & $7.05 \pm 0.12^{\mathrm{A}}$ & $7.09 \pm 0.30^{\mathrm{A}}$ & 0.840 & $10.07 \pm 0.55 \mathrm{AB}$ & $15.74 \pm 0.55^{\text {В }}$ & $<0.001$ \\
\hline A5 $(0.0 / 0.4)$ & $6.63 \pm 0.39^{\mathrm{A}}$ & $7.40 \pm 0.53^{\mathrm{A}}$ & 0.113 & $11.37 \pm 0.35^{\mathrm{B}}$ & $9.27 \pm 0.39^{\mathrm{A}}$ & 0.002 \\
\hline A6 $(0.6 / 0.2)$ & $113.85 \pm 1.25^{\mathrm{D}}$ & $105.28 \pm 0.01^{\mathrm{B}}$ & $<0.001$ & $115.91 \pm 1.06^{\mathrm{E}}$ & $110.45 \pm 0.01^{\mathrm{C}}$ & 0.001 \\
\hline A7 $(0.6 / 0.4)$ & $106.58 \pm 0.69^{\mathrm{C}}$ & $155.52 \pm 0.75^{\mathrm{D}}$ & $<0.001$ & $109.60 \pm 0.84^{\mathrm{D}}$ & $163.94 \pm 0.75^{\mathrm{E}}$ & $<0.001$ \\
\hline A8 $(0.9 / 0.2)$ & $152.30 \pm 0.93^{\mathrm{E}}$ & $296.29 \pm 0.71^{G}$ & $<0.001$ & $168.25 \pm 0.66^{\mathrm{F}}$ & $301.69 \pm 0.71^{\mathrm{H}}$ & $<0.001$ \\
\hline A9 $(0.9 / 0.4)$ & $227.36 \pm 1.26^{\mathrm{G}}$ & $267.48 \pm 1.02^{\mathrm{F}}$ & $<0.001$ & $230.65 \pm 0.36^{\mathrm{H}}$ & $273.57 \pm 1.02^{\mathrm{G}}$ & $<0.001$ \\
\hline $\mathbf{p}^{*}$ & $<0.001$ & $<0.001$ & & $<0.001$ & $<0.001$ & \\
\hline
\end{tabular}

samples: comparison between the setting times obtained by the same mixture with different types of cement.

Through the derivatives method (Table 8 ) the initial setting times between cement $\mathrm{F}$ and cement $\mathrm{Z}$ were statistically equal for mortars $\mathrm{A} 1(0.0 / 0.0), \mathrm{A} 4(0.0 / 0.2)$ e $\mathrm{A} 5(0.0 / 0.4)$. For the final setting time there was only a similarity for $\mathrm{A} 1(0.0 / 0.0)$.

Figure 9 presents a comparison between the initial setting times obtained with cement F (Figure 9a) with cement $Z$ (Figure 9b), estimated by the tangent, direct fraction, and derivatives methods. In general, the results obtained by the three methods of calculus employed demonstrated coherence and proximity with one another.
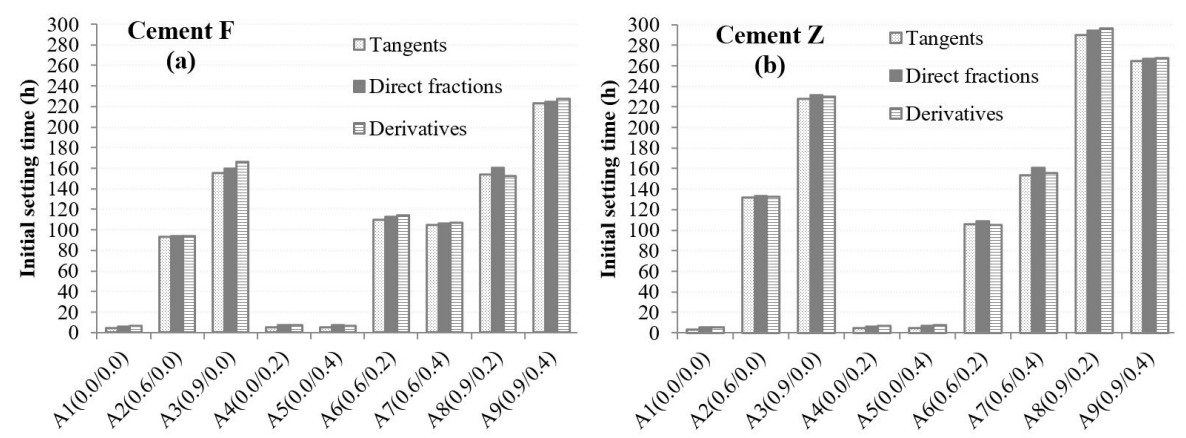

Figure 9. Initial setting times obtained by different methods for mortars with cements $\mathrm{F}$ and $\mathrm{Z}$. 
This way, Figure 10 presents the correlations obtained for the initial setting time obtained by the three methods employed, together with the determination coefficients $\left(\mathrm{R}^{2}\right)$, and Pearson's correlation $(\mathrm{r})$, of the equation of linear tendency. Excellent correlation coefficients between all of the methods were obtained, with the best correlation obtained between the tangent and direct fraction methods (r=0.9998) (Figure 10a).

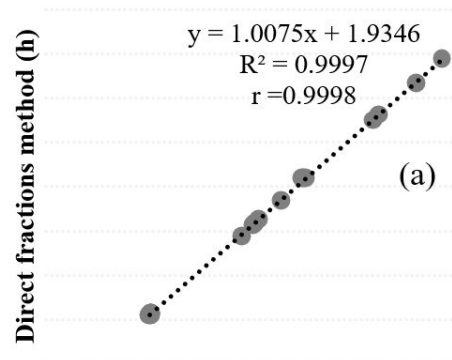

Tangent method (h)

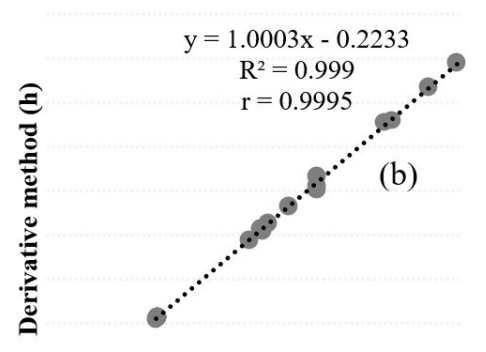

Direct fractions method (h)

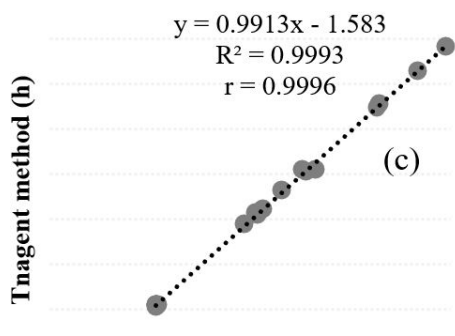

Derivative method (h)

Figure 10. Correlation between the initial setting times obtained by the tangent, direct fraction, and derivatives methods, for mortars with cement $\mathrm{F}$ and cement $\mathrm{Z}$.

Figure 11 presents the final setting times obtained through the tangent, direct fraction and derivatives methods for cement F (Figure 11a) and for cement Z (Figure 11b). The greatest differences between the three methods evaluated were obtained for the final setting times, as shown in Figure 11. These differences are due to the fact that the tangent method consider the end of the setting process only when the temperature reaches the maximum peak after the period of induction [27], [29], [49], while in the other methods the end is considered before, being located close to the half of the period of acceleration [26], [50], [51].
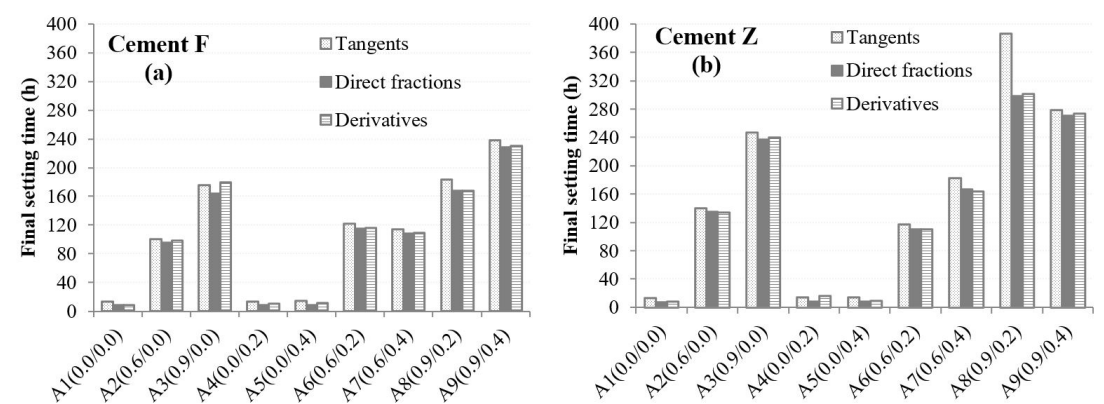

Figure 11. Final setting times obtained by different methods for mortars with cements $\mathrm{F}$ and $\mathrm{Z}$.

Figure 12 presents the correlations found for the final setting times for the three methods together with the determination coefficients $\left(\mathrm{R}^{2}\right)$ and Pearson's correlation (r), of the equation of line of linear tendency.
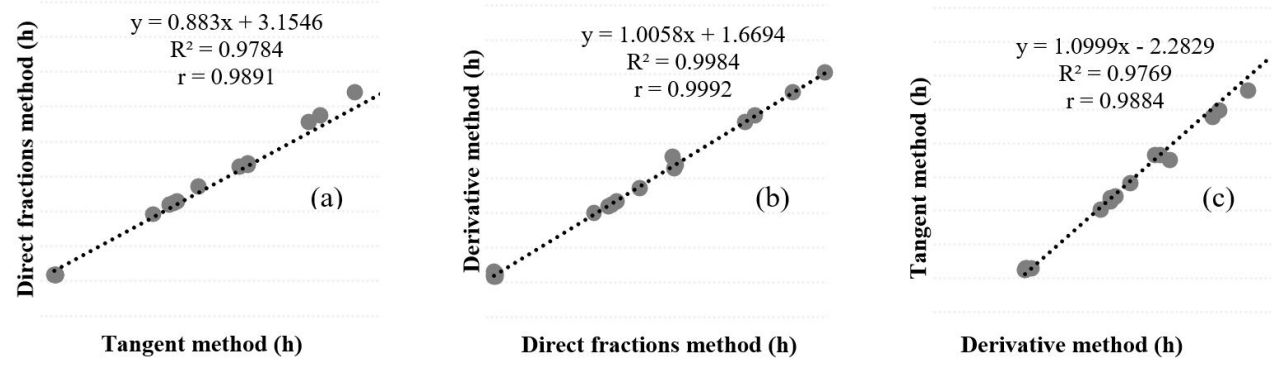

Figure 12. Correlation between the final setting times obtained by the tangent, direct fraction, and derivative methods. 
In all of the correlations for final setting times, coefficients (r) very close to 1.0 were obtained, demonstrating and excellent correlation between the different methods. The greatest correlation coefficient $(r)$ was obtained for the final setting time between the direct fraction and derivatives methods $(r=0.9992)$ (Figure 12b).

Considering the initial and final setting times, the method that best correlated with the other was the one of direct fractions. Therefore, the times established by the direct fraction method were used for the data analysis of this study of the mortars of this study.

\subsection{Analysis of the setting times - Direct fraction method}

As demonstrated on Table 7, for the mixtures without HSA, that is, A1(0.0/0.0), A4(0.0/0.2) and A5(0.0/0.4), the initial and final setting times were statistically equal $\left(\mathrm{p}^{* *}>0.05\right)$ between each other and for the two types of cement, demonstrating that the presence and the rate of admixture did not influence the setting time. Romano [3] also observed that the AEA admixture did not influence the hydration of the Portland cement. Numerically, for these mixtures, the initial setting time of cement $Z$ was smaller than the one of cement $F$. In the mixtures that contained HSA, the initial and final setting times of the mortars with cement $Z$ were very superior $\left(\mathrm{p}^{* *}<0.001\right)$ to the ones obtained with cement $\mathrm{F}$, being up to $84 \%$ superior in $A 8(0.9 / 0.2)$. The exception was for mixture $A 6(0.6 / 0.2)$, which had the initial setting time with cement $\mathrm{F}$ delayed in 4 hours when compared to cement $\mathrm{Z}\left(\mathrm{p}^{* *}=0.013\right)$. This behavior may be explained by the particles of fly ash (contained in cement $Z$ ) being able to absorb the molecules of the HSA admixture, with a continuous poisoning of the growth of the hydrates, slowing down and prolonging the reaction, resulting in peaks of temperature with lower levels and of greater amplitude of base (the mortars with cement $\mathrm{F}$ reached higher temperatures than the mortars with cement F, for the same composition of the mortar - Figure 8). Similar results were obtained by Guindani [13] in admixture pastes.

Figure 13 presents the results of the initial and final setting times obtained for the mortar with HSA and AEA with cement $\mathrm{F}$ and cement $\mathrm{Z}$ by the direct fraction method.
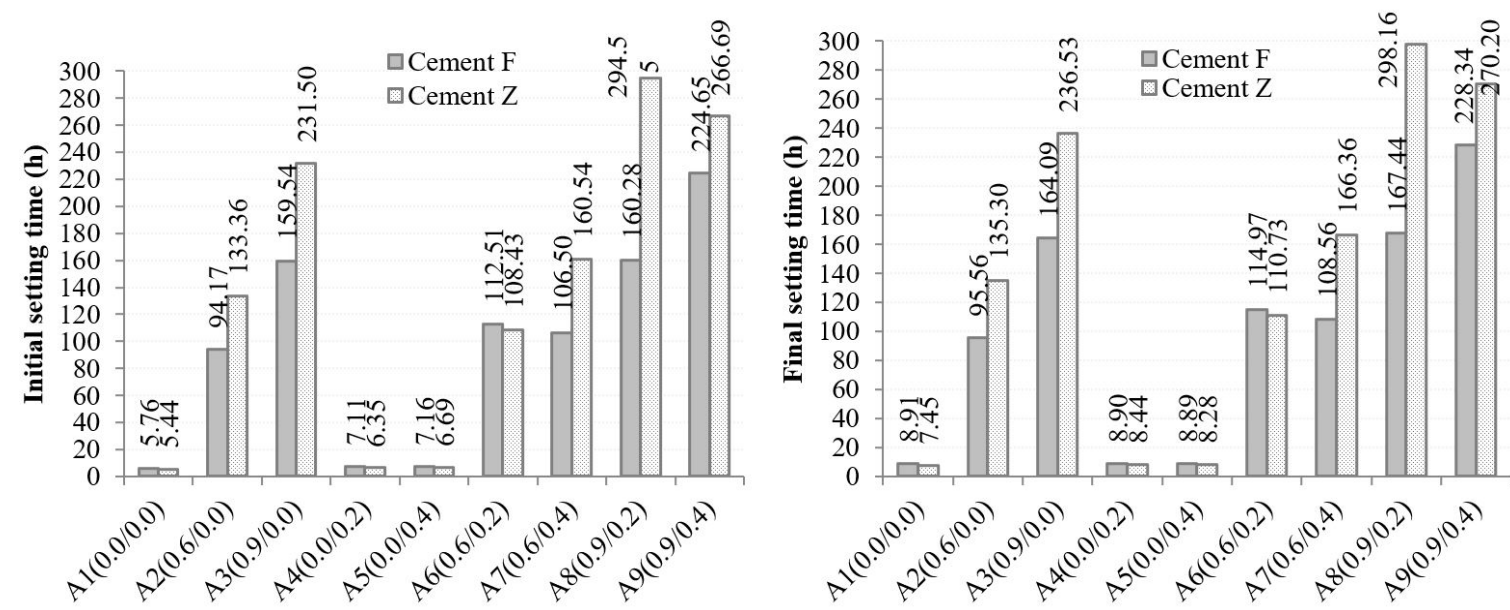

Figure 13. Initial and final setting times for mortars with cements $F$ and $Z$, by the direct fraction method.

By comparing the initial setting time of the same mixtures prepared with the different cements, an increase in the setting time of the mortars with cement $\mathrm{Z}$ in relation to the ones with cement $\mathrm{F}$ was verified of approximately $39 \mathrm{~h}$ of difference in $A 9(0.9 / 0.4)$. In the mortars without AEA the setting times obtained with the two types of cement were similar between one another, that is, they did not present statistically significant differences between their values (Table 7). With the use of HSA, the mortars with cement $\mathrm{Z}$ had a delay in the potentialized setting time. Once the hydration processes from the surface to the inside of the grain, a bigger grain of cement (cement $Z$ ) would, naturally, take longer to hydrate than a smaller one (cement $\mathrm{F}$ ).

According to Trevisol [7] and Souza [9], the admixture forms a film around the grain of cement, which repels the particles of water; therefore, the greater the grain, greater the quantity of molecules of the admixture adhered to cover its surface. On the other hand, it is likely that that the dissolution of this hydro repellent layer may be more difficult with a greater quantity of molecules of admixture adhered; therefore, the greater would be the effect of the delay of the 
setting time. Besides this, cement $\mathrm{Z}$ is a Portland cement composed with pozzolanic material, containing approximately $13.17 \%$ of fly ash, obtained through the test of insoluble residue (Table 2), and, consequently, a greater quantity of clinker, which also influences the speed of the reactions of hydration and consequently the setting time. According to Mehta and Monteiro [4], pozzolanic cement has a slow reaction, consequently the rates of liberation of heat and the development of resistance also occur in a slower way, consuming calcium hydroxide instead of producing it.

By analyzing the mortars of each type of cement, it is observed that, when only HSA is added in the mixtures in its smallest rate studied, the initial setting time is already greater in $88 \mathrm{~h}$ for cement $\mathrm{F}$ - A2(0.6/0.0) and in $128 \mathrm{~h}$ for cement $\mathrm{Z}$ - A3(0.9/0.0), when related to A1(0.0/0.0). This behavior may be explained by the influence of the HAS both in the setting time as well as the heat of hydration of the cement [52].

Figure 14 presents, for the mortars with cement $\mathrm{F}$ (a) and with cement $\mathrm{Z}$ (b), the effect of the increase in the rate of HSA from $0.0 \%$ to $0.6 \%$ and $0.9 \%$ for the mortars with only HAS, mortar with HAS associated with $0.2 \%$ of AEA and mortars with HAS associated with $0.4 \%$ of AEA. In Figure $14 \mathrm{a}$, it is perceived that, for the mortars with cement $\mathrm{F}$, by adding $0.6 \%$ of HSA only - A2 $(0.6 / 0.0)$, the initial setting time increased in $88 \mathrm{~h}$ related to the same mixture with $0.0 \%$ of HSA - A1 $(0.0 / 0 / 0)$. By increasing the HSA from $0.6 \%$ to $0.9 \%$ - A3 $(0.9 / 0.0)$, the initial setting time was elevated to 65 more hours, totalizing a delay in 154 hours when related to the reference- A1(0.0/0.0). In the mortars that associated HSA to $0.2 \%$ of AEA, the increase of the time of the beginning of the setting process with $0.6 \%$ HSA, increasing 48 hours to the delay when used $0.9 \%$ of HSA - A $8(0.9 / 0.2)$. In the mortars that associated HSA to $0.4 \%$ of AEA, there was a delay in the time of the initial setting time of 99 hours with the adding of $0.6 \%$ of HSA- A7 $(0.6 / 0.4)$ in relation to the mortar with $0.0 \%$ of HSA A5 (0.0/0.4). By increasing the rate HSA of $0.6 \%-\mathrm{A} 7(0.6 / 0.4)$ to $0.9 \%$ A9 $(0.9 / 0.4)$, this delay increased in more 118 hours, totalizing a delay of 217 hours in comparison to the mortar without HSA - A5(0.0/0.4).
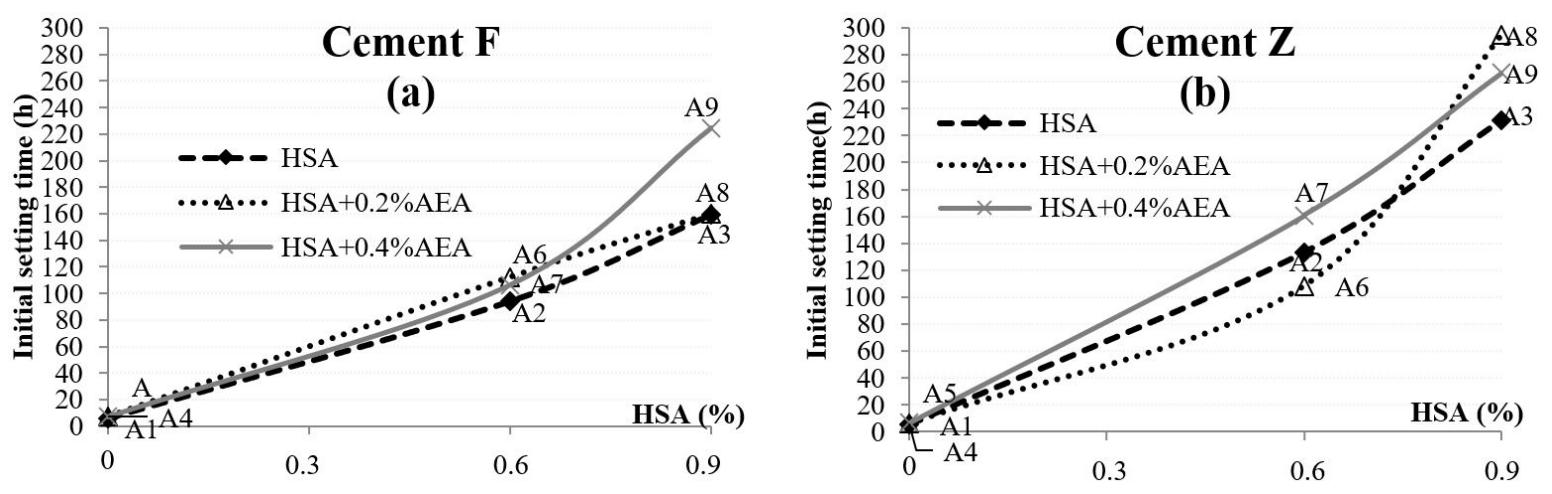

Figure 14. Effect of the increase in the content of HSA at the initial setting time of the mortar.

In Figure $14 \mathrm{~b}$ the results obtained for the mortars with cement $\mathrm{Z}$ are exposed, where 128 hours more in the initial setting time were obtained when adding only $0.6 \%$ of HAS -A2(0.6/0.0), in comparison to the reference - A1 $(0.0-0.0)$. When increased to $0.9 \%$ of HSA - A3(0.9/0.0) the initial setting time was amplified in 98 more hours, that is, a delay of 226 hours related to A1(0.0/0.0). When combined to $0.2 \%$ of AEA, the rate of $0.6 \%$ of HAS - A6(0.6/0.2) offered 102 more hours to the initial setting time in relation to A4(0.0/0.2). Whereas with the rate of $0.9 \%$ of HAS - A $8(0.9 / 0.2)$ a delay of 168 more hours in the initial setting time was verified. For the mortars of $0.4 \%$ of AEA, 145 more hours were obtained during the setting time of $\mathrm{A} 7(0.6 / 0.4)$, in relation to $\mathrm{A} 5(0.0 / 0.4)$, increasing in 106 more hours when employed $0.9 \%$ of HSA - A9(0.9/0.4). This represents a total increase in the setting time of 260 hours, comparing A9(0.9/0.4) with A5(0.0/0.4). These results demonstrate how the adding of HSA, increases the initial setting time of the mortars [13], with more effects for the mortars with cement $Z$ being perceived, as previously discussed.

Observing the action of the AEA in the setting time of the mortars through Table 7, a small increase in the setting time of the mortars admixture with only AEA is observed, in relation to A1(0.0/0.0), for both cements. Statistically the initial setting times of $\mathrm{A} 4(0.0 / 0.2)$ and $\mathrm{A} 5(0.0 / 0.4)$ are not different from $\mathrm{A} 1(0.0 / 0.0)$ (Tukey Post Hoc $=\mathrm{A})$, however, numerically, a small increase in the time only by the use of AEA (up to 1.4hrs) is observed, with no directly proportional relation with the rate employed being observed.

However, when combined to HSA, the evidence of action of the AEA becomes evident, over the reactions of hydration of cement, as observed both in Table 7 as well as Figure 14. When comparing A2(0.6/0.0) with A6(0.6/0.2) 
and A7(0.6/0.4), it is verified that all of the mixtures have the same rate of HAS; however, when AEA is added, 18 ad 12 hours more are obtained, respectively, in the initial setting time for cement $F$ (Figure 14a). Whereas with cement $Z$ (Figure 14b), mortar A6 (0.6/0.2) started the setting process 25 hours before A2 $(0.6 / 0.0)$, while A7(0.6/0.4) delayed 27 hours. When comparing A3(0.9/0.0) with A8(0.9/0.2), no differences were found for the initial setting time of cement F (Figure 14a); whereas for cement Z, there were 63 hours of delay (Figure 14b). Still, when comparing A3(0.9/0.0) with A9(0.9/0.4), there is, for cement F, 65 hours of increase (Figure 14a) and 35 hours for cement $Z$ (Figure 14b). The molecules of ARA may possibly join the molecules of HSA, due to the attraction by opposite charges [3], in such a way that its apolar tail may contribute to a hydro repellent barrier formed around the grains of cement, increasing even more the initial setting time. This way, a distinct behavior when the admixtures are used simultaneously is clearly observed, influencing the initial setting time.

Trevisol and Koman [53] smaller values for the setting times with cement $Z$, in comparison to the ones obtained in this study. The authors obtained 98 hours for the initial setting time of the mortar with $0.6 \%$ of HSA, while in the present study, for this same rate of HAS, 108 to 160 hours were obtained, depending on the rate of AEA associated. However, Trevisol and Koman [53] prepared mortars in factory, with a trace 1:6 $(\mathrm{a} / \mathrm{c}=1.05)$, which may cause differentiated effects on the properties.

Schackow et al. [15] also evaluated the temperature of the ready-mix mortars with CPII Z-32 in a semi-adiabatic calorimeter, obtaining initial setting times close to 50 hours. Besides the traces of distinct admixtures, it was expected that the setting process would occur faster than the similar traces studied in this research, once the authors decreased the quantity of water of the mixtures according to the rates of admixtures employed.

Campos et al. [46] found an initial setting time of 70 hours for the mortar with cement $F-32(1: 6 \mathrm{e} \mathrm{a} / \mathrm{c}=0.87)$ with $0.9 \%$ of HSA, a value very inferior to the one obtained in the present study for the same rate of isolated HSA (159 hours). However, besides the distinct proportion, there are quite different characteristics for the HAS employed and the cement and aggregates, altering the properties of the mixture.

It is worth pointing out that the chemical basis of the HSA admixture combined with the AEA admixture, with distinct rates and compositions, may have influenced the setting time by demonstrating distinction of the results obtained for each study. This way, it is recommended that an evaluation of the interaction of these admixtures with Portland cement, which will be used in the dosage of the ready-mix mortars, be conducted.

For cement $\mathrm{F}$, the following sequence for the beginning of the reactions of hydration, in growing order of the events, was observed: $\mathrm{A} 1(0.0 / 0.0) \stackrel{\sim}{=} \mathrm{A} 4(0.0 / 0.2)) \stackrel{\simeq}{=} \mathrm{A} 5(0.0 / 0.4)<\mathrm{A} 2(0.6 / 0.0)<\mathrm{A} 7(0.6 / 0.4)<\mathrm{A} 6(0.6 / 0.2)<\mathrm{A} 3(0.9 / 0.0)) \stackrel{\simeq}{\simeq}$ $\mathrm{A} 8(0.9 / 0.2)<\mathrm{A} 9(0.9 / 0.4)$. Whereas for cement $\mathrm{Z}$, the sequence suffered some alterations and happened in the following

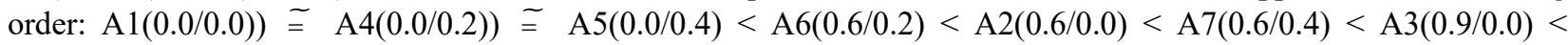
$\mathrm{A} 9(0.9 / 0.4)<\mathrm{A} 8(0.9 / 0.2)$.

These results demonstrated that the AEA may also influence the setting time of the mortars, with significant effects observed when associated to the employment of HSA. However, a direct relationship was only verified between the setting time and the rate of AEA in the mortars with cement $F$ that employed AEA associated to $0.9 \%$ of HSA and for cement $Z$ with AEA associated to $0.6 \%$ of HSA.

In relation to HSA, the initial setting time of the mortars demonstrated having a direct relationship with the rate employed for all cases studied, as shown in Figure 14.

\section{CONCLUSIONS}

With the results obtained, it was verified that the three methods of determination used to estimate the setting times of the mortars demonstrated having a very strong correlation between them. For the analysis conducted, the direct fraction method was chosen because it presented a better correlation with the other methods.

During the period evaluated, a greater temperature in the mortars with Cement $\mathrm{F}$ was verified than with the ones with Cement $\mathrm{Z}$, once cement $\mathrm{F}$ is finer and has a smaller quantity of additions. In the mixtures without admixtures or only with AEA, there were no significant differences found between the setting times with the different types of cement. When HSA was added the effect of the fineness of the cement and the use of admixture in the Portland cement (pozzolanic material) potentialized the increase of the setting time due to the use of the admixtures, with a greater setting time of the mortars prepared with cement $\mathrm{Z}$ being verified.

The initial setting time of the mortars demonstrated having a direct relation with the rate of HSA employed for all of the cases studied, in both cements. The employment of AEA also offered a delay in the setting time of the mortars when associated to the employment of HSA. 
Therefore, it is possible to conclude in this research that for ready-mix mortars, the type of cement and the rate of the admixtures employed, HSA and AEA, influence the setting time, demonstrating clearly the need of a study for the dosage of the ready-mix mortar, once it is commercialized based on its period of time of workability.

\section{ACKNOWLEDGEMENTS}

The authors thank the UFSM for the support, location and resources for the conduction of the research and Supermix and Supertex companies for the supply of materials.

\section{REFERENCES}

[1] R. Rixon and N. Mailvaganam, Chemical Admixtures for Concrete, 3th ed. London: E \& FN SPON, 1999.

[2] H. Carasek, "Argamassas," in Materiais de Construção Civil e Princípios de Ciência e Engenharia de Materiais, G. C. Isaia, Ed., São Paulo: IBRACON, 2010, ch. 28, pp. 893-943.

[3] R. C. O. Romano, "Incorporação de ar em materiais cimentícios aplicadas em construção civil,” M.S. thesis, Esc. Poli, Univ. São Paulo, São Paulo, 2013.

[4] P. K. Mehta and P. J. M. Monteiro, Concreto: Microestrutura, Propriedades e Materiais, 2nd ed. São Paulo: IBRACON, 2014.

[5] American Society for Testing and Materials, Standard Specification for Chemical Admixtures for Concrete, C494, 2004.

[6] R. L. Nelson et al. "Ready mix mortar in the United States," in 8th Int. Brick Block Mason. Conf., 1988, pp. 150-161.

[7] L. A. Trevisol Jr., "Estudo comparativo entre as argamassas: estabilizada dosada em central, industrializada e produzida em obra por meio de ensaios físicos nos estados fresco e endurecido", Ph.D. dissertation, Inst. Eng. Paraná, Curitiba, 2015.

[8] J. Rickert, Influence of Retarders on the Hydration of Clinker and Cement, Concrete Technology Reports 2001-2003. Duesseldorf: Verlag Bau+Technik, 2004.

[9] A. F. Souza, "Otimização do uso de aditivo estabilizador de hidratação do cimento em água de lavagem dos caminhões-betoneira para produção de concreto,” Ph.D. dissertation, Univ. Fed. Santa Catarina, Florianópolis, 2007.

[10] M. Paolini and R. Khurana, "Admixtures for recycling of waste concrete," Cement Concr. Compos., vol. 20, no. 2-3, pp. 221-229, 1998, http://dx.doi.org/10.1016/S0958-9465(97)00066-8.

[11] J. Cheung et al., "Impact os admixtures on the hydration kinetics of portland cement," Cement Concr. Res., vol. 41, no. 12, Dec 2011, http://dx.doi.org/10.1016/j.cemconres.2011.03.005.

[12] W. N. Wczelik and Z. Pytel, "Heat evolution in hydrated cementitious systems ad- mixtured with di erent set controlling components," J. Therm. Anal. Calorim., vol. 77, no. 1, pp. 159-164, Jul 2004., http://dx.doi.org/10.1023/B:JTAN.0000033199.47106.72.

[13] E. N. Guindani, “Argamassa estabilizada para revestimento: avaliação da influência da adição de finos nas propriedades do estado fresco e endurecido,” Ph.D. dissertation, Prog. Pós-grad. Eng. Civ., Univ. Fed. Santa Catarina, Florianópolis, 2018.

[14] J. Dransfield, "Admixtures for concrete, mortar and grout," Adv. Concr. Technol., vol. 3, pp. 3-36, 2003., http://dx.doi.org/10.1016/B978-075065686-3/50280-9.

[15] A. Schackow, A. K. Ferrari, C. Effting, V. O. Alves, and I. R. Gomes, "Stabilized mortar with air incorporator agent and plasticizer set retarder: performance measurement," Rev. IBRACON Estrut. Mater., vol. 12, no. 6, pp. 1248-1259, Dec 2019., http://dx.doi.org/10.1590/s1983-41952019000600002.

[16] L. G. Couto, Admixture Handout, disciplina de Civ 361 - Materiais de Construção Civil II. Viçosa: Universidade Federal de Viçosa, 2011.

[17] D. Lootens and D. P. Bentz, "On the relation of setting and early-age strength development to porosity and hydration in cementbased materials," Cement Concr. Compos., vol. 68, pp. 9-14, 2016., http://dx.doi.org/10.1016/j.cemconcomp.2016.02.010.

[18] J. M. Casali et al., “Avaliação das propriedades do estado fresco e endurecido da argamassa estabilizada para assentamento e revestimento," in An. IX SBTA, 2011.

[19] L. M. L. Calçada, A. E. Gaio, and M. G. Ramos, "Estudo da influência da dosagem no tempo de início de pega da argamassa estabilizada," in Sem. Pesq. Inov. IFSC, 2013.

[20] G. Macioski, “Avaliação do comportamento de argamassas estabilizadas para revestimento,” Undergraduate thesis, Univ. Fed. Paraná, 2014.

[21] G. M. Campos, "Estudo do tempo de início de pega de argamassas com aditivo estabilizador de hidratação," Specialization thesis, Univ. Tecnol. Fed. Paraná, Curitiba, 2012.

[22] S. M. Ruppenthal and F. Pelisser, "Estudo de argamassas de revestimento com inibidores de hidratação", Undergraduate thesis, Univ. Ext. Sul Catarin., Criciúma, 2012. [Online]. Available:

http://repositorio.unesc.net/bitstream/1/1158/1/Suelem\%20Michels\%20Ruppenthal.pdf 
[23] D. M. Pivetta et al., "Desempenho de argamassas estabilizadas: influência do aditivo estabilizador de hidratação no estado fresco" in An. $58^{\circ}$ Cong. Bras. Concr., 2016.

[24] Associação Brasileira de Normas Técnicas, Concreto e Argamassa - Determinação dos Tempos de Pega por Meio de Resistência a Penetração, NBR NM 9, 2003.

[25] C. S. Barbosa et al., "Estudo da influência da quantidade de água no tempo de pega em pastas e em argamassas estabilizadas" in $A n$. XIII Simpósio Bras. Tecnol. Argamassas, 2019.

[26] M. J. C. Viecili, D. Hastenpflug, and R. Girardi, "Comparativo entre o teste de Vicat e a calorimetria semi-adiabática para determinação do tempo de início e fim de pega em cimentos Portland," Rev. Materia, vol. 23, no. 3, 2018. http://dx.doi.org/10.1590/s1517-707620180003.0506.

[27] P. K. Mehta and P. J. M. Monteiro, Concreto: Estrutura, Propriedades e Materiais, 2nd ed. São Paulo: Ed. Pini, 1994.

[28] E. G. R. Petrucci, Concreto de Cimento Portland, 13th ed. São Paulo: Globo, 1998.

[29] A. M. Neville and J. J. Brooks, Tecnologia do Concreto, 2nd ed. Porto Alegre: Bookman, 2013.

[30] Associação Brasileira de Normas Técnicas, Cimento Portland e Outros Materiais em Pó - Determinação da Massa Específica, ABNT NBR 16605, 2017.

[31] Associação Brasileira de Normas Técnicas, Cimento Portland - Determinação do Índice de Finura por Meio da Peneira $75 \mu m$ (no 200), ABNT NBR 11579, 2013.

[32] Associação Brasileira de Normas Técnicas, Cimento Portland - Determinação da Pasta de Consistência Normal, ABNT NBR $16606,2018$.

[33] Associação Brasileira de Normas Técnicas, Cimento Portland - Determinação dos Tempos de Pega, ABNT NBR 16607, 2018.

[34] Associação Brasileira de Normas Técnicas, Cimento Portland - Análise Química - Determinação de Perda ao Fogo, ABNT NBR NM 18, 2012.

[35] Associação Brasileira de Normas Técnicas, Cimento Portland - Análise Química - Método de Arbitragem para Determinação de Dióxido de Silício, Óxido Férrico, Óxido de Alumínio, Óxido de Cálcio e Óxido de Magnésio, ABNT NBR NM 14, 2012.

[36] Associação Brasileira de Normas Técnicas, Cimento Portland - Análise Química - Determinação de Anidrido Sulfúrico, ABNT NBR NM 16, 2012.

[37] Associação Brasileira de Normas Técnicas, Cimento Portland com Adições de Materiais Pozolânicos - Análise Química - Método de Arbitragem, ABNT NBR NM 22, 2012.

[38] Associação Brasileira de Normas Técnicas, Cimento Portland e Outros Materiais em Pó - Determinação da Finura pelo Método de Permeabilidade ao Ar-Método de Blaine, ABNT NBR 16372, 2015.

[39] Associação Brasileira de Normas Técnicas, Cimento Portland-Determinação da Expansibilidade Le Chatelier, ABNT NBR 11582, 2016.

[40] Associação Brasileira de Normas Técnicas, Cimento Portland - Determinação da Resistência à Compressão de Corpos de Prova Cilíndricos, ABNT NBR 7215, 2019.

[41] Associação Brasileira de Normas Técnicas, Agregados - Determinação da Composição Granulométrica, ABNT NBR NM 248, 2003.

[42] Associação Brasileira de Normas Técnicas, Agregado Miúdo - Determinação da Massa Especifica e Massa Específica Aparente, ABNT NBR NM 52, 2009.

[43] Associação Brasileira de Normas Técnicas, Agregados - Determinação da Massa Unitária e do Volume de Vazios, ABNT NBR NM 45, 2006.

[44] Associação Brasileira de Normas Técnicas, Agregados - Determinação do Material Fino que Passa Através da Peneira 75 um, por Lavagem, ABNT NBR NM 46, 2003.

[45] J. P. Antoniazzi, "O efeito dos aditivos incorporador de ar e estabilizador de hidratação nas propriedades das argamassas estabilizadas”, M.S. thesis, Univ. Fed. Santa Maria, Santa Maria, 2019.

[46] G. M. Campos, G. Macioski, and J. M. Casali, "Estudo do tempo de início de pega de argamassas com aditivo estabilizador de hidratação" in Anais 55 Cong. Bras. Concr., 2013.

[47] R. W. Weakley, "Evaluation of semi-adiabatic calorimetry to quantify concrete setting", M.S. thesis, Fac. Auburn Univ., Auburn, Alabama, USA, 2010. [Online]. Available: http://hdl.handle.net/10415/1981

[48] P. Sandberg and S. Liberman, "Monitoring and evaluation of cement hydration by semi-adiabatic Field calorimetry," in Concrete Heat Development - Monitoring, Prediction and Management, K. Wang and A. K. Schindler, Eds., Georgia, NY: Curran Associates, 2007.

[49] H. F. W. Taylor, Cement Chemistry, 2nd ed. London: Academic Press, 1997. http://dx.doi.org/10.1680/cc.25929.

[50] V. S. Ramachandran, Concrete Admixtures Handbook, 2nd ed. New York: Noyes Publications, 1984. 
[51] I. Jawed, J. Skalny, and J. F. Young, "Hydration of Portland cement," in Structure and Performance of Cement, P. Barbes, Ed., London: Applied Science Publishers, 1983.

[52] B. E. Watts and C. Ferraro, "Prediction of setting for admixture modified mortars using the VCCTL," Cement Concr. Compos., vol. 78, pp. 63-72, 2017.

[53] L. A. Trevisol Jr. and D. F. Koman, "Estudo da interferência do uso de cal hidratada no tempo de estabilidade em argamassas estabilizadas dosadas em central" in An. XIII SBTA, 2019.

Author contributions: Antoniazzi: experimental results, data analysis and discussion, writing. Mohamad and Casali: conceptualization, methodology, supervision.

Editors: Edgar Bacarji, José Luiz Antunes de Oliveira e Sousa, Guilherme Aris Parsekian. 